\title{
The Education System Development \\ in Kyzyl During the First Decade after Tuva's Integration in the USSR
}

\author{
Regina O. Shirap* \\ Tuvan State University \\ 36 Lenin Str., Kyzyl, Republic Tuva, 667000, Russia
}

Received 15.09.2016, received in revised form 29.06.2017, accepted 10.07.2017

The article deals with the education system development in Kyzyl in the first decade after Tuva has become a part of the USSR. The main source of the article was periodical press, considering the newspapers as the most popular source of information in the considered period. Moreover, the periodical press played an important role as a mediator between the population and authorities. For example the readers had an opportunity to address their letters about social, cultural or economic problems in Kyzyl to the edition of "The Tuva Pravda"; after that the citizens could have an official response from the authorities in the newspaper. Basing on the periodical press and documents of the Central State Archive of the Republic of Tuva, the conclusion has been drawn that the education system was highly developed within that short period. For example, the first primary schools in the Tuva region were opened in 1930, but in 1952 they already had their Kyzyl Pedagogical Institute and the population could provide with the teachers by themselves. However, there were some defects of the education system related to incorrect methodical skills of the teachers, weak control of the department of education, poor technical equipment and insufficient number of classrooms.

Keywords: education, science, Kyzyl, schools, Kyzyl Pedagogical Institute, department of education, "The Tuva Pravda", periodical press.

DOI: 10.17516/1997-1370-0111.

Research area: national history.

The Republic of Tuva is one of the youngest regions of the Russian Federation which in 2014 celebrate its $70^{\text {th }}$ anniversary from the date of its voluntary joining to the USSR basing on the rights of autonomous entity and the centenary of its capital's - Kyzyl - founding. These jubilee celebrations contribute to increased public interest towards the Republic's history and, particularly, to Kyzyl.
Tuva's first years in the USSR mainly reminded a critical time in its history: that was the period with total involvement of the Tuvinian society into the value orientations of the Soviet Union. Such wide-scaled changes in the population's life as the integration into the Soviet Republic brotherhood caused fundamental changes in all the spheres of life. Mainly it concerns the system of education which

(C) Siberian Federal University. All rights reserved

* Corresponding author E-mail address: Reggylook@gmail.com 
alongside with other tasks ensures the Tuvinians with confidence in the right choice for the Soviet way of life.

\section{Problem Statement}

As it is known, the national writing in Tuva appeared just in 1930 that launched the education system development which at that time included only the elementary level. Only in 1940, in Kyzyl, there the first 7-classes school was founded which then received the secondary form in April, 1944.

The success of public education is seen through growing number of schools in this region. Thus, in 1936 Tuva included only 17 schools, in 1939 this number increased almost in 4 times, and in 1946 there were 122 Tuvinian and Russian schools. Right in the end of 1946 the total number of students was 13, 4 ths people (Uspekhi iskusstva..., 1946: 2).

Unfortunately, we have failed to find any information about the number of educated people in Kyzyl over the concerned period of time; what is known that in 1945 three of Kyzyl schools were attended by nearly 1300 students and in 1947 this indicator increased up to $2700^{1}$.

One of the urgent problems in the capital's education system was a poor financial support for the teachers. In 1946 it was said to the executive committee by Frolkova ${ }^{2}$, thr Head of the Town Department of Public Education. Many of the teachers were not provided with the housing, manufactured goods were also poorly delivered to them and the service in the teachers' dining room remained low. To improve this situation, the Executive Committee of the Town Council encharged the municipal utilities service to transfer three flats to the Education Department; the heads of trading organizations were instructed to take measures to eliminate the weaknesses. The Department of Public Education was assigned to improve the housing conditions for the teachers and assist in cattle, goats and poultry purchasing ${ }^{3}$.
Before the new school buildings were put into their operation, the classes were held in adapted rooms. That is why there was an acute problem of overcrowded classes. Thus, in 1947 in Kyzyl School № 1 the classes consisted of nearly 60 people that significantly damaged the lessons ${ }^{4}$. The solution came in 1948 with the end of construction of two secondary schools on the edge of the capital. Each of these new schools was designed for 124 students (Stroitel'stvo..., 1948: 3). In this context, in 1948 the capital had three secondary schools available. At that time in Kyzyl as well as in a number of other districts of the autonomous region the obligatory general education was implemented. The census of children aged 7-15 showed that in 1948/1949 school year these three schools taught more than 2600 students.

Apart from these schools Kyzyl also had a night school initiated for young workers and used to educate almost 300 people in 1948. There was a note appeared in the newspaper by T. Skakova, a she-student of that school, which said that "the number of students could have been bigger if the classes were organized properly" (Skakova, 1948: 3).

According to her, the majority of students gave up the school due to a low level of teaching, since even the principal (Mr. Ovchinnikov) came unprepared for the classes quite often. Belkina and Shashkova, the teachers of the Russian language, not once missed the classes without any reasonable excuse. T. Skakova also mentioned about an indifferent attitude towards the night school from the employees of the Town Department of Public Education who had never controlled the school processes, although "the Head of the Town Department of Public Education, Mr. Chuzhinov, was well aware about the classes' organization in the night school".

The respond was given by the Regional Department of Public Education in a month 
where everything stated by T. Skakova had been proved (Po sledam nashikh..., 1949: 3). The Head of the Town Department of Public Education, Mr. Chuzhinov, was reprimanded for a formal and bureaucratic management over the school and the night school's principal was given a severe reprimand with a warning. Those teachers who had no professional education were also fired and replaced by well-qualified young personnel.

By 1950 a favorable environment for successful operating of the night school was created: it was completely equipped with the learning materials, manned with the teaching staff and provided with the facilities belonged to the School № 3. Nevertheless, the studies and educational work in the school for young workers suffered from many weaknesses, related mainly to negligence from the administration and ordinary teachers. This was reflected in many mass media publications. Thus, the article "Neporyadki v shkole rabochei molodyozhi" (eng. - "Mess in the School for Young Workers" by V. Varshavskaya reports on a poor academic performance inside the school, mainly, as she thinks, due to a careless attitude of some teachers to their duties and absence of any control from the administration (Varshavskaya, 1950: 3).

The school also held a streaming of students, though, the school administration did not make any efforts to terminate it. The decline in academic performance and undermined discipline (truancies and tardy) which were pointed out in another article by V. Varshavskaya, directly derived from the poor academic organization, since there had been often changes in the class schedule, the classes were held in unsafe medical conditions quite frequently. The bottom line of the article was the accent on the youth's desire to be educated and necessity to create conditions for useful education by the nongovernmental organizations located in the capital. However, judging by the article "Bolshe vnimaniya vechernei shkole rabochei molodyozhi” (Eng. -
"More Attention towards the Night School for Young Workers") published in 1952 by V. Mezhova, no improvements in the school operating had been made (Mezhova, 1952: 2).

The author pointed out the previous weaknesses related to misconduct and low level of academic performance. V. Mezhova also marked a bad relationship between the head teachers and production entities where the students worked; that remained one of the leading reasons of regular truancies and absences. The author reported on the cases of students being late at work, particularly of those who worked at the road transport departments. The similar content was laid in the article by M. Shur-ool, in 1955, who wrote that the school was almost missed by publishers, garment workers, the medicalforensic office and regional hospital staff (Shurool, 1955: 3).

The author explains such decline through the absence of attention to the school from the side of the regional department of public education where the inspectors were hardly interested in the organization of teaching and educative work and did not provide the teachers with any methodological guidance.

The problem of the night school activity was discussed at the meeting of the Town Council of Working People's Deputies in February, 1956, reporting the growth in the number of teachers achieved a complete academic success. Nevertheless, the quality of lessons still remained low; the problem with attendance also continued to be. The meeting resulted in the executive committee's resolution to demand from $\mathrm{Mr}$. Cherednichenko, the night school's principal, and Ms. Berednikova, the deputy principal, to eliminate all the pointed weaknesses. Besides, it was agreed to demand from the directors of enterprises, institutions and production facilities to create the necessary environment for those who studied at the school for young workers so as they 
could attend the school on the job and maintain a close contact with the school administration.

Apart from the above, the schools in Kyzyl had to cope with a number of other problems. Thus, concerning proceedings of the town party conferences, we have discovered that all schools faced with the problem of overcrowded classes, school failures, poor academic, methodological and educative work by the teachers, and lack of administration control and management of the Town Department of Public Education. Quite often the schools' principals reported on a poor workplace discipline of both the teachers and students. In particular, in May, 1946, Mr. Ivanov, the principal at the Secondary Russian School, gave a speech at the plenary meeting of the AllUnion Communist Party (the Bolsheviks) Town Committee about his work; he reported about the letters of the religious nature breaking into the school that had distracted the students from their learning process. Moreover, time and again the students hanged out in the cinema at nights, and "inappropriately spent the holidays - they had parties with wine". The principal emphasized that neither the society, nor the party entities paid any attention to such behavior of the students ${ }^{5}$.

Educational institutions in the town desperately needed the teaching staff since the training was provided only outside Tuva. Thus, to solve this problem, in July 1946, there was a resolution made by the All-Union Communist Party (Bolsheviks) Town Committee for Mr. Chuzhinov, the head of the Town Department of Education, and for the school principals to prohibit firing the teachers without offering alternative staff ${ }^{6}$.

The hopes about changing this situation were related to foundation of the Teacher Training College in 1945 (Kornev, 1945: 3). The regional newspaper included a request for the admission of students in this college for first and preparatory years for 1948/1949 academic period
(Kyzyl'skoe pedagogicheskoe..., 1948: 1). The first year enrols 14-25 aged applicants who had finished the 7-classes school. The preparatory courses were designed for people of the same age educated with not less than 6 classes as well as for the children of Tuvinian cattle breeders and collective farmers. Besides, the applicants were provided with residence apartments and fully supported from the state, while the Russian students got only a scholarship. As can be seen from the above, the autonomous region's government paid special attention to qualified personnel development among the native population through different benefits.

In 1952, Kyzyl Pedagogical Institute the first institution of higher education - was established. The staff was taught there in three directions: in the Tuvinian language and literature, Russian language and literature, and mathematics and physics. Initially, the material and technical basis of the Institute was extremely weak, since it had no building; the faculty included 10 teachers: P.N. Nikish, A.A. Slemenev, A.S. Ivanov, V.P. Bartsevich, Ye.I. Skripov, K.A. Generalov, Ye.I. Kopteva, K.Kh. Orgu, V.V. Poluboyaryanova, V.T. Grinev; the science degree was given only to A.A. Selemenev (Candidate of Science, History).

There also were the party, komsomol and trade-union entities which significantly supported the administration in strengthening discipline, teaching and educative work enhancement and recreational activities for the students. At the end of the academic year, P. Nikish, the Director of Kyzyl Pedagogical Institute, reported on the first results of the new Institute's performance (Nikish, 1953: 3). It was observed that over one year the educational infrastructure of the Instituted had greatly been strengthened; 200 ths rubles had been spent to equip the classrooms and the library included 14 ths of books. Additionally, there was significant improvement in the teaching and 
educative work of the faculty - they held a number of academic conferences dedicated to the works by I.V. Stalin, literature evenings, sport competitions and organized different clubs. P. Nikish mentioned about the necessity to speed up the construction of 8-flats residential building for the teachers; the Institute also felt the need of an additional space for the student halls of residence, since in the new, 1953/1954 academic year the amount of student had considerable increased.

In another way, the scientific success was marked by the establishment of Research and Development Institution of Language, Literature and History which at that time became a place for the rise of Tuvinian studies and other active researchers in the human sciences. The assistance of academic researchers (Tuva National Research Institute of Language, Literature and History) made it possible to provide the students and teachers with the required textbooks on major schools subjects. At the same time, the Institute raised an active collection of the materials on folklore, history and ethnography of the Tuvinian people.

\section{Conclusion}

Therefore, the development of education in Kyzyl during the first decade after Tuva's integration into the USSR in 1944 was determined by political changes. Meanwhile, that period was marked by the transformation the social consciousness of the traditional Tuvinian ethnos. One of the major criteria of the person's social status involves education. It increases the social interest to educational institutions performance and to the problems of staff training reflected in numerous publications in the local newspapers.

Over that short period of time the system of education has achieved certain results. While in 1930s there was only the primary education, in 1944 the secondary schools of general education developed and 1945 was marked by the appearance of training colleges which gave an opportunity to provide the autonomous region with well-skilled staff. The launch of the higher education was in 1952 with the establishment of Kyzyl Pedagogical Institute. In the context of national region the problem of national intellectual development through the benefits for the native population on their admission to colleges and institute was particularly important.

The reported period witnessed the launch of Tuva studies as a scientific branch. The establishment of Tuva National Research Institute of Language, Literature and History in 1945 allowed supplying many schools with essential textbooks and guidances written in the Tuvinian language in particular.

Despite such undeniable success in this sphere, a number of weaknesses still remained. The students' academic performance kept low caused by overcrowded classes, poor teaching and educative training of the teachers, negligence towards the duties from the side of administrations and Town Department of Public Education.

\footnotetext{
The State Archive of the Republic of Tuva, Ф. 3., Оп. 1, Д. 3. Л. 48.

The State Archive of the Republic of Tuva, Ф. 37. Оп. 1. Д. 1. Л. 419.

Ibid, Д. 1. Л. 420.

Ibid, Д. 4. Л. 23.

The State Archive of the Reoublic of Tuva, Ф. 3. Оп. 1. Д. 12, Л. 55.

The State Archive of the Reoublic of Tuva, Ф. 3. Оп. 1. Д. 14. Л. 27.
}

\section{References}

Gosudarstvenniy arkhiv Respubliki Tuva [The State Archive of the Republic of Tyva], F. 3. Op. 1. D.1. Gosudarstvenniy arkhiv Respubliki Tuva [The State Archives of the Republic of Tyva], F. 37. Op. 1. D.3, $12,14$. 
Kornev G. (1945). K otkrytiyu pedagogicheskogo uchilischa [On the Establishment of Pedagogical College], In Tuvinskaya pravda [The Tuva Pravda], 3 (November).

Kyzyl'skoe pedagogicheskoe uchilish he ob'yavlyaet nabor [Kyzyl Pedagogical College Announces Admission] (1948). In Tuvinskaya pravda [The Tuva Pravda], 30 (May).

Mezhova V. (1952). Bol'she vnimaniya shkole rabochei molodezhi [More Attention to School for Young Workes], In Tuvinskaya pravda [The Tuva Pravda], 2 (February).

Nikish P. (1953). Nashi pervye itogi [Our First Results], In Tuvinskaya pravda [The Tuva Pravda], 3 (July).

Po sledam nashikh vystuplenii [In the Wake of Our Performances] (1949). In Tuvinskaya pravda [The Tuva Pravda], 3 (January).

Seifulin Kh. M. (1952). V Tuvinskom institute yazyka, literatury i iskusstva [In Tuva Institute of Language, Literature and Art], In Tuvinskaya pravda [The Tuva Pravda], 3 (March).

Seyfulin Kh. M. (1946). Tuvinskij nauchno-issledovatel'skij institut yazyka, literatury i iskusstva [Tuva Research Institute of Language, Literature and Art], In Tuvinskaya pravda [The Tuva Pravda], 2 (June).

Shur-ool M. (1955). Oni dolzhny uchit'sya [They Should Study], In Tuvinskaya pravda [The Tuva Pravda], 3 (March).

Skakova T. (1948). Kogda vechernyaya shkola budet rabotat' normal'no? [When the Night School Will Work Properly?], In Tuvinskaya pravda [The Tuva Pravda], 3 (December).

Stroitel'stvo novykh shkol [Building New Schools] (1948). In Tuvinskaya pravda [The Tuva Pravda], 3 (May).

Uspekhi iskusstva i narodnogo obrazovaniya v Tuve [The Success of Art and Public Education in Tuva] (1946). In Tuvinskaya pravda [The Tuva Pravda], 2 (November).

Uchenye zapiski TNRILLH [Scientific Notes of Tuva Research institute of Language, Literature and History] (1953). In Tuvinskaya pravda [The Tuva Pravda], 3 (November).

Varshavskaya V. (1950). Neporyadki v shkole rabochei molodezhi [Mess in the School for Young Workers], In Tuvinskaya Pravda [The Tuva Pravda], 3 (January).

\section{Развитие системы образования в г. Кызыле в первое десятилетие после вхождения Тувы в состав СССР}

P.O. Ширап

Тувинский государственный университет Россия, 667000, Республика Тыва, Кызыл,

ул. Ленина, 36

В статье рассмотрены особенности развития системы образования в г. Кызыле в первое десятилетие после вхождения Тувы в состав СССР. На основе анализа материалов периодической печати, архивных документов Государственного архива сделан вывод о том, что система образования в столице Тувинской автономной области получила широкое развитие. 
Так, если в 1930 г. имелось только начальное образование, то уже в 1952 г. область могла сама обеспечить себя педагогическими кадрами с высшим образованием. Тем не менее наряду с успехами выявлены и недостатки в работе образовательных учреждений, что автор связывает с плохой учебно-методической работой педагогов, отсутствием контроля со стороньл Городского отдела народного образования, плохой технической оснащенностью учебных заведений и недостаточным количеством учебных помещений.

Ключевые слова: образование, наука, Кызыл, школа, Кызылский педагогический институт, городской отдел образования, газета «Тувинская правда», периодическая печать.

Научная специальность: 07.00.02 - отечественная история. 